\title{
Arundhati Roy's The God of Small Things (TGST): Diaspora
}

\author{
Shiva Zaheri Birgani ${ }^{1}$, Maryam Jafari ${ }^{2}$ \\ ${ }^{1}$ Department of English Language and Literature, Boroujerd Branch, Islamic Azad University, Boroujerd, \\ Iran \\ ${ }^{2}$ Islamic Azad University, Science and Research Branch, Tehran, Iran \\ Shvzaheri@gmail.com
}

\section{Abstract}

This paper attempts to analyze the mentioned novel based on postcolonial studies in Arundhati Roy's The God of Small Things. The concepts that can be mentioned in this novel are history, diaspora, hybridity, the role of women in Indian society, globalization, resistance and orientalism. These concepts are used from postcolonial theorists, Homi $K$. Bhabha . Colonization is a period of time. This is history itself. In developing the dominance of colonization, writers played a main role. Knowledge and power are the dominating themes that over-rule the deep nature of imperialism and literature. These themes indicate the superior literature, culture and tradition as the standard form of acceptance. Colonization is a period of time. This is history itself. In the result of the colonization, the migration and transition were not avoidable issues. Therefore, in this displacement, the new identity has been made. People's customs, cultures and beliefs are mixed with colonizers' unconsciously. India is a multicultural country. There are many various cultures in this country. And also during the colonization and the dominance of Britain over India, the changes were made in its customs and cultures. Arundhati Roy is an Indian writer and female activist.

Keywords

postcolonialism resistance; diaspora; hybridity, goldoalization; orientalism

\section{Introduction}

In this chapter, the present researcher is going to discuss some issues in details in TGST. The present researcher writes about the novel's author, the novel itself, and the synopsis of TGST in separated items. There are various layers of history in TGST. The history of Syrian Christians in South India, the history of The Caste System in Hinduism, Velutha as the Hindu God, Krishna, Kathakali Dance in Kerala, Naxalites in Kerala. There are some special and capital words in TGST such as, Big God, Small God, Small Things, History House, Ayemenem House, and God of Loss. These words are outlined in the bottom of history. Diaspora is another issue which is discussed in the present chapter. Diaspora has taken place in various layers of Indian history. The novel is semiautobiographical in that it incorporates, embellishes, and greatly supplements events from her family's history. It takes place in Ayemenem, a village in the southwestern India state of Kerala, in 1969 and 1993. India is a very complex society with various cultural and religious habits and beliefs. Hindus, Buddhists, Christians and Muslims share the same space Society is divided not only by the very strict caste system but also by class consciousness. There are a number of languages spoken in India, but the higher classes make a point of speaking English, sending their sons to study in England and adopting certain English habits. 
Kerala is a small India. This is a complex society too. It has a complex social setup with Hindus, Muslims and Christians having lifestyle and traditions different from each other. It also has the largest number of Christian population compared to other parts of India, predominantly Saint Thomas Christians or Syrian Christians. Kottayam is a district where the Christians are a majority. In more modern history, Kerala achieved statehood in 1956 after existing as part of the Travancore-Cochin region since India's independence in 1947. Kerala's official language is Malayalam, although it is not uncommon for inhabitants to be familiar with several other languages from neighboring territories. Inhabitants have included Portuguese, Dutch, British, rulers from all over India, and religious groups escaping persecution in their own countries. Kerala is lauded for its outstanding progress in the areas of cleanliness, education, and quality of life. The tourism board of Kerala boasts that it is not only India's cleanest state but also has a literacy rate above ninety percent and the highest physical quality of life in India. In Roy's TGST (2007), Tickell states:

Postcolonialism is a more influential perspective. Postcolonialism involves a range of the economic, cultural and ideological experience of European colonialism and its historical legacy. These features were shown in the writings of colonized countries. India is one of these countries. The Indians apply the English language to articulate their own identities after, and in opposition to colonial rule. In the novel Indian situations and characters are models for postcolonial outlook. (72)

TGST covers a broad historical spectrum: pre-colonial; British colonial; Postcolonial; Hindu, Christian and Communist. In Kerala, the ancient and social religious tradition that produced the Hindu caste system refuses to give way to the new, postcolonial present which sees a Communist Kerala heralding new economic opportunities. Kerala is a place at once spiritual and secular-where God meets Marx and kathakali dancers meet American cable television. It is a place where Communists have been elected to power since 1957 and are subsequently in government until this present day. For Roy, Kerala is a place where communism betrays common people and the god that presides is 'small god' limited and dissipated by the prevailing society.

\section{Review of Literature}

In Commonwealth Literature in English, Dr. Amar Nath Prasad considered a study in TGST's theme and technique. Ronald Bogue wrote and essay about childhood and becominguntouchable in TGST. This essay was printed in Deleuzian Fabulation and the Scars of History. Scot Trundell is and independent scholar with a bachelor's degree in English literature. He wrote an essay about the significance of the sexual encounters between Rahel and Estha, and Ammu and Velutha.

Joyce Hart is a writer who he studied Roy's poetic language and unique writing style. Laura Carter is a freelance writer. She considered the social malaise present in Roy's version of conemporary Indian society as a function of Western influence. Douglas Dupler is a writer and a teacher who examined the relationship between individuals and the cultural forces acting upon them within the novel. Ritu Menon believed that TGST is about childhood and the loss of innocence.

Two French critics, Carole Durix and Jean-Pierre Durix, examined TGST from psychoanalytic, post-structural and postmodern perspectives. Also, R. K. Dhawan examined this novel from gender issues, transgression and linguistic aspects. In the field of postcolonial studies, Dhawan organized a study about history. Here, the focus will be mostly history, diaspora, hybridity, postcolonial resistance, the role of women in Indian society, globalization and orientalism 


\section{Research Methods}

The present researcher tries to analyze the novel based on some postcolonial concepts. Hybridity is based on White who believes that history is the title of scientific discipline in the nineteenth century. In postcolonial regions, there is migration and transition of the different nations always. In the result of this transition of the peoples, the new identities had been made. This condition creates transcultural identity. Hybridity became significant concept in postcolonial studies. The present researcher tries to work on diaspora and hybridity from Bhabha's view. The writer and the character of Ammu are women. And they belong to diasporic community, the researcher wants to work on the role of women in Indian society. Other concepts are resistance and orientalism. Said worked on the two last concepts. The process of the world shrinking and becoming a single place refers to globalization. This happens in complex society. India tries to inject foreign investment for globalization.

\section{Discussion}

\subsection{Communism in Kerala}

Robert Joung in his book Postcolonialism (2001), says that "there are two historical strains during the liberation struggle" (350). These two are "Gandhi and Communist Party" (ibid). Firstly, Gandhi mixed Hindu, Islamic, Buddhist and Christian ideas, but not as a form of religion. This is his political style against the British Empire for unifying his nation. Because India is consisted of "many different cultures and religions" (ibid 338). This hybrid mode was the secret of his popularity, of how he achieved "the active support not only of the Indian Hindu bourgeois elite" (ibid 346). He believed that all religions derived from the same God. He said that it may be noble thoughts from all over the world come to us. This belief was "one of his favourite maxims" (ibid). Secondly, Marxism is a division within the Indian independence movement. This division continued to play itself out in postcolonial India..

Roy remarks the first period of communism in Kerala in TGST, when she writes "Suddenly the communist found themselves in the extraordinary - critics said absurd position of having to govern a people and foment revolution simultaneously" (TGST 32). In the first period of communism in Kerala, they presented unfavourite bills, such as the ending of concessionary fares for students, faced strikes and civil unrest. Tickell, in his book Arundhati Roy's The God of Small Things (2007), states that "when the war between China and India took place in 1962, a split made in the party"S (29). Moreover the leadership scandal caused "a number of CPI members to leave and form the Communist Party of India (Marxist), CPI (M)" (ibid). This new party was under E. M. S. Namboodiripad. This party believed that it was "as the real inheritor of the undivided CPI" (ibid).

According to almost all feminist scholar's patriarchy refers to rule of the father in a male dominated society as a social and ideological construct which regards men as superior to women. They are of opinion that men's domination over female sexuality is central to women's subordination. In fact, man is the head of the family who controls women's sexuality, labor, production, reproduction and mobility. Moreover, the effect of patriarchy can be traced in politics, public life and economy as well as in all aspects of social, personal, psychological and sexual existence.(Raoufzadeh,60)

They focused on developing rural power based at a regional rather than national level. They received "a victory in the 1967 elections in Kerala" (ibid 30). This party continued for thirty-one months before succumbing to internal conflict, but the communists "remain an active presence in the politics of the state" (ibid). Although the CPI had a limited role in national politics, it was "successful in Kerala and Bengal" (ibid). In TGST, Roy wants to 
express the cause of this success. However Chacko has not complete explanation for this success when he speaks about it. But Roy's significant argument is given below:

There were several competing theories. One was that it had to do with the large population of Christians in the state. Twenty percent of Kerala's population were Syrian Christians [...] Structurally - this some what rudimentary argument went - Marxism was a simple substitute for Christianity. Replace God with Marx, Satan with the bourgeoisie, Heaven with a classless society, the Church with Party, and the form and purpose of the journey remained similar. (TGST 32)

These sentences show a cause of this success. This is the replacement theory of communism, because they admitted existing religious and cultural structures. They filled a break created by the decline of Hindu and Christian social and religious structures in 1940s. Tickell, in his book Arundhati Roy's The God of Small Things (2007), states that "although personal privilege does not necessarily adjust radical politics, the family background of Kerala's communist leader E. M. S. Namboodiripad encapsulates the political contradictions of his brand of peaceful communism" (30).

Another cause of this success refers to the famously high levels of literacy in Kerala. Roy points out that the communist administration made these literacy levels (Tickell 30). Roy believes that this success refers to the working of the Communist Party within the existing power structure:

The real secret was that communism crept into Kerala insidiously. As a reformist movement that never overtly questioned the traditional values of caste-ridden, extremely traditional community. The Marxists worked from within the communal divides, never challenging them, never appearing not to. They offered a cocktail Hinduism, spiked with a shot of democracy. (TGST 32)

Tickell, in his book Arundhati Roy's The God of Small Things (2007), maintains that Communism shifts Kerala's society from a barbaric past to enlightened Marxist view (31). Communist political strategy was not to identify completely with any group. Roy draws the strategic aspects of the CPI (M) and its growing complacency in TGST. This is in the figure of Comrade K. N. M. Pillai who is a cynical demagogue. His house was where "midnight study meetings were held" (TGST 7) and "the red had bled away" (TGST 8). His house was "a place of study meetings and revolutionary fervor" (Tickell 31).

Basirizadeh in his article mentions that, "In de Beauvoir's view if women really want a status, they should deconstruct the structures of the masculine society and present their own definition of feminity. This definition would be the proof of woman's presence and existence counter-intuitive to masculine canon of knowledge in power"(2).

\subsection{Big God, Small God, Small Things, History House, Ayemenem House, God of Loss}

Roy says that something happened when personal turmoil dropped by at the wayside shrine of the vast, violent, circling, driving, ridiculous, insane, unfeasible, public turmoil of a nation. "That Big God howled like a hot wind, and demanded obeisance. Then Small God came away cauterized, laughing numbly at his own temerity" (TGST 10).

Priyamva Gopal, in his book Indian English Novel (2009), said that "Small Things" represents "a coming-of-age for the Anglophone family novel" (156). With its emphasis on sensory and emotional experience as well as its deft knitting together of the familiar and the exotic (Gopal 156). This was a novel with a clear storyline, empathetic characters, identifiable villains, and an original literary style that was both musical and completely accessible. The family dynamics seemed both identifiably universal and pleasingly culturally particular. Roy's novel proffered a masterly command of realism and the pleasures of seemingly unmediated experience. 
Small Things makes brilliant use of personal memories to reconstruct the events of a childhood at once idyllic and tragic and in particular, the fateful evening when three children set out on an unsupervised boating expedition. Literary childhood is always a construct but here it is brilliantly crafted. "The juxtaposition of the relatively innocent juvenile consciousness of the twins and the adult Rahel's disabused mind is also compelling" (ibid). Childhood is a time without divisions whereas now: "Edges, Borders, Boundaries, Brinks and Limits have appeared like a team of trolls on their separate horizons" (TGST 3). Nation and History are parts of this team, legislating and dividing human experience (Gopal 157). Indian history is focused on the nation-state, which determines how the past is to be read; this can be undone by listening to the myriad 'small voices' in civil society.

Roy suggests the very smallness of personal despair in the face of great national turmoil that makes it the source of powerful stories. Where Big God controls the writing of official histories, Small God "climbed into people's eyes and became an exasperating expression" (TGST 10). If the nation is the dominant story, then individual are constitutively subaltern (Spivak 1999: 27). The novel shows the picture of the downtrodden oppression or marginal group, those who stand with Spivak's colonial discourse "the subaltern cannot speak" (ibid). Roy's command of metaphor and imagery flourish in her invocation of the aesthetics of the small: "a bird in flight reflected in old dog's balls" (TGST 7); silences sitting between two people like a third person; childhood fleeing while "flailing its thin arms" (TGST 61); fear lying "rolled up on the car floor like a damp cheroot" (TGST 34). The telling of the story falls then to Rahel and the resultant narrative revels in speech and the glories of language, at times with thrilling inventiveness and at others with clumsy excess. Gopal, in his book Indian English Novel (2009), said that a bilingual sensibility where English is not taken for granted as a first language opens up literary possibilities in this novel, which is constantly aware of the joys and pitfalls of language acquisition (157). We could see the following sentence for this bilingual sensibility: "Thang God," Estha said. "Thank God, Estha," Baby Kochamma corrected him" (TGST 74).

The brutal killing of Ammu's "untouchable" lover, Velutha, by "Touchable" policemen begets a series of schematic explanatory maxims: "a blind date with history" (TGST 133); "History in live performance" (TGST 144). The events of that tragic day happen in Ayemenem. Other generalizations proliferate: “civilizations' fear of nature, men's fear of women, and power's fear of powerlessness" (TGST 144). Man subliminal urge to destroy what he could neither subdue nor deify. Gopal, in his book Indian English Novel (2009), maintained that Roy suggests that "desire, proscription, and family structures are entities that change historically" (157). At its best, the novel connects "the personal to historical and social realities"; at its crudest, it dwindles into "a schematic history lesson" in which the reader is bludgeoned into accepting rather than reflecting on the relationship between the two (ibid). This was particularly linked to diaspora, who sought to find history and identity in an imagined homeland.

Sara Upstone, in her book Spatial Politics in the Postcolonial Novel (2009), states that personification of houses represents spaces with specific identities, it is difficult to reduce to allegorical function (123). This feature is common in postcolonial narratives. for example, the Ayemenem House is personified with an identity of its own in TGST. It is a house that "wore its steep, gabled roof pulled over its ears like a low hat" (TGST 2). Moreover, "politicization of the home is not only a negative factor prompting lament for a lost ideal, but also the potential for new interruptions" (Upstone 131). In TGST, for example, the home's reflection of wider political represents "the positive potential of the invasion of politics into the home: the way in which domesticity displaces the nation from centre-stage and allows 
alternative sites of identification" (ibid). Roy mentioned about two houses in TGST the Ayemenem House and the History House. Upstone believes that:

Thus although the History House is a space of 'moral corruption and spiritual degeneration, a symbol of colonial authority that is also reflective of India's communal conflicts, it also provides opportunities for the reversal of these against its colonial past. The status of the History House in the world of the postcolony announces a refusal to be indeterminately defined by this relationship. Chacko says that the house is locked, and therefore that the past is no longer available to the autochthonous citizens who would try and enter. (Ibid 132)

The present researcher believes Chacko shows this matter in his behavior when he returns to his Hindu beliefs and do not allow Ammu to marry Velutha. And he tries to keep his position as a superior citizen in Kerala. Locking the History House represents that Chacko remains in his past and do not allow the other citizens to enter this house. But Estha, Rahel, Ammu and Velutha do enter. When Velutha and Ammu have the relation with each other outside the History House, it represents the linkage between caste developments and increased control over sexual relations, so present in the Ayemenem House. Their relation becomes dissolved in this alternative domestic space. It shows the power of individuals to make changes to their circumstances, however limited.

David Punter in his book Postcolonial Imaginings: Fictions of a New World Order (2000), maintains that "Loss exists everywhere postcolonial writing" (130). Roy introduces "God of Loss" (ibid 153). Roy refers to Velutha as both "The God of Small Things" and "The God of Loss" (TGST 153). Roy uses from "Small Things" and the "small perspective" throughout the novel (ibid). "Big" can be as a human being's and as "Small" as a cabbagegreen butterfly's. There are many different stories that make the novel, not a definitive story in TGST. There is the terror of history in Roy's TGST. This represents past too. TGST gives us a world of ghosts. The researcher believes that although "God of Loss" is labeled to Velutha, we can see the trace of this in "the twins' life" (ibid). The novel represents the fact that Estha was silent for many years and that Rahel has a kind of emotional emptiness, a void or misgiving. The twins' conditions are a kind of Loss. The plot forces us learn "the reasons for these evidently traumatic effects" (Punter 72).

\subsection{Diaspora in the Novel}

Migration and diaspora are concerns of postcolonialism. Roy criticizes traditional forms of cultural practice, including patriarchal societies, or religious and ethic groupings in her book with regard to feminism and nationalism. With regard to diasporic literature, a whole new set of questions arises. The diasporic writers we are looking at often describe very new problems and circumstances. They often talk about how enabling it can be for women to be in a different kind of community. This different kind of community can be the complex community of Kerala. Roy shows how the everyday is lived and is loaded with complexity. It shows how grand scale national politics cannot be understood without that micro-vision. The migration of Syrian Christians is significant migration in the novel. Roy remarks the history of Syrian Christian.

Four migrations are pointed in TGST. The first refers to Syrian-Christian community to Kerala. Kerala's population were Syrian Christians, who believed that they were descendants of the one hundred Brahmins whom Saint Thomas the Apostle converted to Christianity when he travelled east after Resurrection. The second refers to Chacko's migration to Britain. The third refers to Rahel's migration to America. The fourth refers to Father Mulligan's migration to India. He is an Irish priest who comes to Kerala for studying Hinduism. And 
finally he converts to Hinduism. The present researcher believes that it may constitute hybrid and diasporic identity in the result of these migrations.

The character of Rahel, which is similar in many aspects to Arundhati's eventful life, deals, briefly, with the diasporic existence. Her TGST is semi-autobiographical and mixes her childhood experiences in Aymanam with a postcolonial scrutiny of history and relationships. Traditionally, the diaspora has been represented as a division, some kind of a loss, a draining, and eternal longing for what could be and was elsewhere, the home somewhere else, retained in the imagination, preserved like Arundhati Roy's famous pickling factory pickling exotic pickles.

Communism Party was successful in Kerala. Chacko had no really complete explanation for why the Communist Party was so much more successful in Kerala than it had been almost anywhere else in India, except perhaps in Bengal. Although Roy tries to answer to this success, the present researcher believes that because Kerala's community was complex and diasporic community. And according to Communism, the people must be equal to each other. Thus Communism was more successful and it had followers in this region.

The present researcher believes that there are some issues of diasporic language in complex Indian society. We can these diasporic issues in TGST. When the Moguls invaded Iran and the Iranians converted them into ambassadors of the Iranian language. They made Persian or Parsi their court language in India. Parsi was the language of the court of many of the Indian kings till the British banned its use, after occupying India in the eighteenth century. Roy uses four diasporic words which are originated from Persian and then they come in English. We can see these words in the following sentences: when Roy writes "His family were once-wealthy zamindars who had migrated to Calcutta from East Bengal after partition" (TGST 19), she speaks about Ammu's husband. The word "zamindars" in this sentence shows diasporic feature in TGST. Roy writes "They did [...] caught in the bazaar - branded them so that everybody would know them for what they were" (TGST 77). Roy writes "He lived in a caravan" (TGST 78). In another example, she writes "Baby Kochamma wrote for her father: My dearest Papa, [...] But Koh-i-noor appears to be unhappy and homesick" (TGST 13). As Roy described about the name "Koh-i-noor" belongs to a Muslim person. It is a name of a girl. The researcher believes that this is a sign of diasporic communities in India, especially in Kerala. This belongs to Pharsi community, because this is a Persian word.

\section{Conclusion}

Indian history and politics shape the plot and meaning of The God of Small Things (TGST) in a variety of ways. Some of Roy's commentary is on the surface, with jokes and snippets of wisdom about political realities in India. However, the novel also examines the historical roots of these realities and develops profound insights into the ways in which human desperation and desire emerge from the confines of a firmly entrenched caste society. Roy reveals a complex and longstanding class conflict in the state of Kerala, India, and she comments on its various competing forces.

For example, Roy's novel attacks the brutal, entrenched, and systematic oppression at work in Kerala, exemplified by figures of power such as Inspector Thomas Mathew. Roy is also highly critical of the hypocrisy and ruthlessness of the conventional, traditional moral code of Pappachi and Mammachi. On the opposite side of the political fence, the Kerala Communist Party, at least the faction represented by Comrade Pillai, is revealed to be much more concerned with personal ambition than with any notions of social justice.

The caste system is along with an economic class struggle. The Ipes are considered upper class. They are factory owners, the dominating class. Mammachi and Baby Kochamma 
would not deign to mix with those of a lower class. Even Kochu Maria, who has been with them for years, will always be a servant of a lower class. The main events of the novel are traced back through the complex history of their causes, and memories are revealed as they relate to each other thematically and as they might appear in Rahel's mind. Roy also employs a disjointed, nonsequential narrative that echoes the process of memory, especially the resurfacing of a previously suppressed, painful memory. The book's last chapter was removed because of its graphic description of sexual acts between members of different castes. Roy's assertions throughout the novel imply that the caste system still greatly affects present-day Indian society.

A high-caste male with British education such as Chacko, and the caste system which made by mythological ideas are able to be kept intact through the various layers of history. The Anglophile Chacko who makes this insightful statement about Indian history: "our minds have been invaded by a war. A war that we have won and lost. The very worst sort of war. A war that captures dreams and re-dreams them. A war that has made us adore our conquerors and despise ourselves" (TGST 26). Chacko believes that the "war of dreams" is a war of histories. It refers to a struggle of competing visions of Indian society. His notion of history presupposes it as a meta-narrative, where colonized persons would be denied a place in the grand historical narrative. Roy believed that history cannot be separated into clearly defined categories, problematic though that may be. And the caste system and sexual discrimination survive all political regimes and various layers of history. The "war of histories", that is, two layers of history: spiritual and secular and the Sanskrit mythological past and post-colonial present and their uneasy co-existence in present-day India. Roy refers to the "dreams that fueled the freedom struggle" (ibid).

In the novel, Indian situations and characters are models for postcolonial outlook. Migration and diaspora are main concerns in postcolonialism. There are various historical layers in TGST. Some migrations are mentioned in the novel. The present researcher believes that diaspora and migration took place in these historical contexts.

\section{References}

Ashcroft, Bill et al. (2002). The Empire Writes Back .London and New York: Routledge, ---. (2007). Postcolonial Studies (The Key Concepts). New York: Routledge.

---. (2006). The Postcolonial Studies Reader. New York: Routledge.

Basirizadeh, Fatemeh. (2019). A Comparative Study of the Psychoanalytical Portrayal of the Women Charactersby Virginia Woolf and Zoya Pirzad. Britain International of Humanatis and Social Sciences Journal, 1-8.

Harasym, Sara. (1990). The Postcolonial Critic. London: Routledge.

Gaeini, M. Basirizadeh, F. (2019) The Role of social Identity in James Joyce`s Dubliners within theLight of Cultural Materialism., 89-99.

Loomba, Ania. (2000). Postcolonial Studies. London and Durham: Duke University Press.

Mashale, Dr. Ashok. (2011). "The Postcolonial Perspectives in Indian English Novels". Indian Stream Research Journal: 32-3.

Raoufzadeh, N. Mohammadhosein,Sh. Zaheri Birgani, Sh. (2019) Analysis of Love, Death, Rebirth and Patriarchy in Two Contemporary Poetess Forough Farrokhzad and Sylvia Plath's Selected Poems. Budapest International Research and Critics Institute-Journal, 56-64.

Roy, Arundhati. (1998).The God of Small Things. Islamabad: Harpernnial,

Said, Edward.(2003). Orientalism. London: Penguin Books. 
Said W, Edward. (1993). Culture and Imperialism. New York: Vintage Books, Schwarz, Henry and Sangeeta, Ray.A Companion to Postcolonial Studies, UK: Blackwell Publishing,

Sharp, Jenny. (1999). Allegories of Empire. The Figure of Woman in the Colonial Text. London and Minneapolis: University of Minnesota Press, Spivak, Gayatri. A Critique of Postcolonial Reason. Massachusetts: Harvard University.

Tickell, Alex. (2007). Arundhati Roy's the God of Small Things. New York: Routledge. 